\title{
KEWENANGAN PEMERIKSAAN KEUANGAN TAHUNAN BPK OLEH AKUNTAN PUBLIK MENURUT UNDANG-UNDANG NOMOR 15 TAHUN 2006 TENTANG BADAN PEMERIKSAAN KEUANGAN
}

\author{
${ }^{1}$ Zaki Al Abrar, ${ }^{2}$ Nuribadah, ${ }^{2}$ Hasan Basri \\ ${ }^{1}$ Mahasiswa Fakultas Hukum, Universitas Malikussaleh \\ ${ }^{2}$ Dosen Fakultas Hukum Universitas Malikussaleh
}

\begin{abstract}
Abstrak
Akuntan public adalah salah satu jenis profesi bidang akuntansi yang menawarkan jasa professional terkait bidang akuntansi yang seesuai standar berlaku dan telah mendapatkan izin dari negara serta berhak melakukan praktik di Indonesia yang bekerja secara idependen ,yang melatar belakangi penulis untuk mengkaji permasalahan ini ialah terkait dengan tata cara pemilihanan ggota akuntan public yang menurut penulis terdapat kekeliruan. Studi ini bertujuan untuk menjelaskan menjelaskan kewenangan Akuntan Publik dalam melakukan pemeriksaan pengelolaan keuangan dan mekanisme pemeriksaan pengelolaan keuangan tahunan BPK oleh akuntan publik menurut Undang-undang nomor 15 tahun 2006 tentang Badan Pemeriksaan Keuangan. Metode penelitian yang digunakan dalam penelitian ini adalah jenis penelitian yuridis normatif. Pendekataan penelitian yang dilakukan lebih ditujukan kepada pendekatan undang-undang, pendekatan konseptual, dan pendekatan komperatif. Adapun sifat penelitian dalam skripsi ini adalah penelitian deskriptif, Serta bentuk dari penelitian ini adalah bentuk preskriptif.
\end{abstract}

Kata Kunci : Kewenangan,BPK,Akuntan Public 


\section{PENDAHULUAN}

Undang-Undang Dasar Negara Republik Indonesia tahun 1945 telah mengatur mengenai keuangan Negara, dalam Pasal 23 ayat (5) yang berbunyi: "untuk memeriksa tanggung jawab tentang keuangan Negara diadakan suatu Badan Pemeriksaan Keuangan, yang peraturanya ditetapkan dengan Undang-undang. Hasil pemeriksaan itu diberitahukan kepada Dewan Perwakilan Rakyat". Undang-Undang Dasar 1945 Pasal 23 ayat (5) diatas sangat jelas bahwa Indonesia memiliki suatu lembaga yang bertanggung jawab atas keuangan Negara yaitu Badan Pemeriksaan Keuangan (BPK). Badan Pemeriksaan Keuangan (BPK) adalah lembaga Negara yang bertugas untuk memeriksa pengelolaan dan tanggung jawab keuangan Negara.Badan Pemeriksaan Keuangan (BPK) merupakan satu lembaga Negara yang bebas dan mandiri, berkaitan dengan pelaksanaan atau realisasi anggaran pendapatan dan belanja Negara yang telah disetujui oleh rakyat melalui DPR.Badan Pemeriksaan Keuangan pada pokoknya adalah partner atau mitra DPR dalam menjalankan fungsi pengawasan (control) terhadap kinerja pemerintahan, serta mengawasi pelaksanaan anggaran pendapatan dan belanja Negara. Hasilhasil pemeriksaan keuangan yang telah dilakukan kemudian diberitahukan atau disampaikan kepada DPR atau ditindak lanjuti sebagaimana mestinya. ${ }^{1}$

Keberadaan Badan Pemeriksaan Keuangan didalam penyelenggaraan Negara dipertegas dalam UUD 1945 setelah perubahan, dalam Pasal 23 ayat (1) UUD 1945 disebutkan untuk memeriksa pengelolaan dan tanggungjawab keuangan Negara diadakan satu Badan Pemeriksaan Keuangan yang bebas dan mandiri. Dari pengaturan diatas sangat jelas bahwa segala sesuatu tanggungjawab yang memeriksa keuangan Negara dari berbagai instansi itu dipegang oleh BPK, namun yang menjadi pertanyaannya siapakah yang bertanggung jawab memeriksa keuangan BPK tersebut, apakah BPK itu sendiri atau ada lembaga lainnya, dalam hal ini Badan Pemeriksaan keuangan diperiksa oleh akuntan publik yang sudah ditetapkan oleh DPR dan Menteri Keuangan.

Undang-undang Nomor 15 tahun 2006 tentang Badan Pemeriksaan Keuangan Pasal 32 ayat (1) Pemeriksaan pengelolaan dan tanggung jawab keuangan tahunan BPK dilakukan oleh akuntan publik, ayat (2) Akuntan public sebagaimana yang dimaksud pada ayat (1) ditunjuk oleh DPR atas usul BPK dan Menteri Keuangan, yang masing-masing mengusulkan 3 (tiga) nama akuntan public, ayat (3) Akuntan public sebagaimana yang dimaksud pada ayat (2) dalam 2 (dua) tahun terakhir tidak melakukan tugas untuk dan atas nama BPK atau memberikan jasa kepada BPK, ayat (4) Hasil pemeriksaan sebagaimana dimaksud pada ayat (1) diserahkan kepada DPR dengan salinan kepada Pemerintah untuk penyusunan laporan keuangan Pemerintah Pusat. ${ }^{2}$

Berdasarkan Undang-undang Nomor 15 Tahun 2006 tentang Badan Pemeriksaan Keuangan sudah sangat jelas terlihat didalam ayat 2 bahwa akuntan publik itu ditunjuk oleh DPR atas usul BPK dan Menteri Keuangan yang masing-masing mengusulkan tiga nama akuntan publik. Merujuk dari ayat 2 tersebut sangatlah jelas terlihat bahwa dalam pemeriksaan keuangan tahunan BPK oleh Akuntan Publik yang diusulkan oleh pihak BPK tersendiri dengan kata lain BPK ikut mengambil bagian dalam menentukan para anggota calon akuntan publik yang akan ikut mengaudit pihaknya tersendiri.

Merujuk kepada Peraturan Pemerintah Nomor 20 Tahun 2015 tentang Akuntan Publik sebagaimana terdapat didalam pasal 1 ayat 1 yang berbunyi Akuntan Publik adalah seseorang

1 Rini Wulandari, Skripsi: Badan Pemeriksaan Keuangan Dalam Kajian Ketatanegaraan Islam,Fakultas Syariah dan Hukum Universitas Islam Negeri Syarif Hidayatullah, Jakarta 2008, Hal. 1

${ }^{2}$ Ibid., 
yang telah memperoleh izin untuk memberikan jasa sebagaimana diatur dalam Undang-undang Nomor 5 Tahun 2011 tentang Akuntan Publik. Adapun bunyi dari ayat ke 2 yaitu Asosiasi Profesi Akuntan Publik, yang selanjutnya disebut asosiasi profesi adalah organisasi profesi akuntan publik yang bersifat nasional.Kemudian diatur lebih lanjut juga dalam PP No. 20 Tahun 2015 pasal 2 ayat 1 "asosiasi profesi berwenang menyelenggarakan ujian profesi akuntan publik.Akuntan publik adalah bagian dari salah satu profesi yang harus mengikuti suatu ujian profesi untuk bisa mendapatkan sertifikat sebagai akuntan publik.

Akuntan Publik merupakan profesi yang lahir dan besar dari tuntutan publik akan adanya mekanisme komunikasi independen antara entitas ekonomi dengan para stakeholder terutama berkaitan dengan akuntabilitas entitas yang bersangkutan. ${ }^{3}$ Tugas Akuntan Publik meliputi analisis laporan keuangan, audit laporan keuangan, audit pajak dan sebagainya. Menurut Otoritas Jasa Keuangan ( $\underline{\mathrm{OJK}}$ ) akuntan publik adalah akuntan yang memiliki izin praktik dari pemerintah sebagai akuntan swasta sehingga dapat memberikan jasa akuntansi kepada perusahaan dengan mendapatkan pembayaran tertentu (public accountant). Akuntan publik juga harus memastikan tidak ada penyelewengan, manipulasi, ataupun tindakan yang menyimpan,g dan penyalahgunaan sumber daya di suatu perusahaan atau lembaga. Dan seorang akuntan harus menjadi anggota Institut Akuntan Publik Indonesia (IAPI) sebagai asosiasi profesi akuntan publik yang telah diakui oleh pemerintah agar bisa mengaudit laporan keuangan.

Profesi Akuntan Publik juga memiliki peranan yang sangat besar dalam mendukung perekonomian nasional yang sehat dan efisien serta meningkatkan transparansi dan mutu informasi dalam bidang keuangan. Akuntan Publik tersebut mempunyai peran terutama dalam peningkatan kualitas dan kredibilitas informasi keuangan atau laporan keuangan suatu entitas.Dalam hal ini Akuntan Publik mengemban kepercayaan masyarakat untuk memberikan opini atas laporan keuangan suatu entitas.Dengan demikian, tanggung jawab Akuntan Publik terletak pada opini atau pernyataan pendapatnya atas laporan atau informasi keuangan suatu entitas, sedangkan penyajian laporan atau informasi keuangan tersebut merupakan tanggung jawab manajemen. ${ }^{4}$

Membangun kredibilitas BPK dan melaksanakan Pasal 32 UU Nomor 15 Tahun 2006 tentang BPK yang menyatakan bahwa Pemeriksaan pengelolaan dan tanggung jawab keuangan tahunan BPK dilakukan oleh akuntan publik, disini disebutkan bahwa Akuntan Public memang sangatlah jelas memiliki kewenangan untuk memeriksa pengelolaan dan tanggung jawab tahunan BPK.

\section{METODE PENELITIAN}

Berdasarkan latar belakang di atas, permasalahan yang akan dibahas dalam penulisan skripsi ini adalah sebagai berikut: Pertama, Bagaimanakah kewenangan Akuntan Publik dalam melakukan pemeriksaan pengelolaan keuangan tahunan BPK menurut Undang-undang Nomor 15 tahun 2006 Tentang Badan Pemeriksaan Keuangan. Kedua, Bagaimanakah mekanisme pemeriksaan pengelolaan keuangan tahunan BPK oleh akuntan publik menurut Undang-undang

\footnotetext{
${ }^{3}$ Mardiasmo, PerwujudanTransparansi dan Akuntabilitas Publik melalui akuntasi sector Publik, Jurnal Akuntansi Pemerintahan, VOL 2 No. 1 Mei 2006.

4 Marulak Pardede Dkk, Laporan Akhir Penelitian Hukum tentang Hak dan Tanggungjawab Akuntan Publik dalam Pemeriksaan Keuangan Negara, Badan Pembinaan Hukum Nasional Kementerian Hukum dan Ham RI 2011. Hlm. 21
} 
Nomor 15 tahun 2006 Tentang Badan Pemeriksaan Keuangan. Jenis penelitian yang digunakan adalah penelitian hukum normatif. Penelitian hukum normatif mengacu pada berbagai norma hukum, dalam hal ini adalah hukum positif khususnya dibidang Pemerintahan yang menyangkut Kewenangan Pemeriksaan Keuangan Tahunan BPK oleh Akuntan Publik menurut Undangundang Nomor 15 tahun 2006 tentang Badan Pemeriksaan Keuangan. Penelitian ini menggunakan pendektan perundang-undangan.Pendekatan perundang-undangan digunakan untuk mengetahui peraturan yang berkenaan dengan hukum Tata Negara.

\section{PEMBAHASAN}

\section{Tinjauan Yuridis Tentang Kewenangan Akuntan Publik}

Menurut kamus besar bahasa indonesia, kata wewenang disamakan dengan katakewenangan, yang diartikan sebagai hak dan kekuasaan untuk bertindak,kekuasaan membuat keputusan, memerintah dan melimpahkan tanggung jawabkepada orang/badan lain. ${ }^{5}$

Hukum Administrasi Negara tentu kita tidak asing mendengar istilah wewenang, karena sebenarnya wewenang sekaligus menjadi batasan kekuasaan untuk berbuat sesuatu dan tidak berbuat sesuatu.Secara umum Wewenang dalam Hukum Administrasi Negara adalah Kekuasaan menggunakan sumberdaya untuk mencapai tujuan organisasi dan secara umum tugas di definisikan sebagai kewajiban atau suatu pekerjaan yang harus dikerjakan seseorang dalam pekerjaannya. Menurut kamus besar bahasa indonesia, kata wewenang disamakan dengan kata kewenangan, yang diartikan sebagai hak dan kekuasaan untuk bertindak, kekuasaan membuat keputusan, memerintah dan melimpahkan tanggung jawab kepada orang/badan lain. ${ }^{6}$

Peraturan Pemerintah Nomor 20 Tahun 2015 tentang Akuntan Publik yang berkaitan dengan pembatasan jasa audit yang terdapat dalam Pasal 10 ayat 1, 2 dan 3 yaitu:

1. Akuntan publik memberikan jasa asuransi yang meliputi:
a. Audit atas informasi keuangan historis;
b. Jasa review atas informasi keuangan historis; dan
c. Jasa asuransi lainnya.

2. Selain jasa asuransi sebagaimana yang dimaksud dalam ayat 1 , akuntan publikdapat memberikan jasa lainnya yang berkaitan dengan akuntansi keuangan dan manajemen.

3. Pemberian jasa sebagaimana yang dimaksud pada ayat 1 dan 2 dilakukan sesuai dengan ketentuan peraturan perundang-undangan.

Menurut Frans Magnis Suseno kewenangan adalah kekuasaan yang dilembagakan.Menurut H.D Stoud kewewenangan adalah keseluruhan aturan-aturan yang berasal dari hukum organisasi pemerintahan, yang dapat dijelaskan sebagai seluruh aturanaturan yang berkenaan dengan perolehan dan penggunaan wewenang-wewenang pemerintahan oleh subjek hukum publik didalam hubungan hukum publik. ${ }^{7}$

Menurut G.R.Terry Wewenang dalam Hukum Administrasi Negara adalah kekuasaan resmi dan kekuasaan pejabat untuk menyuruh pihak lain supaya bertindak dan taat kepada pihak yang memiliki wewenang itu, Menurut R.C.Davis dalam bukunya, Fundamentals of

\footnotetext{
${ }^{5}$ Kamal Hidjaz, Efektifitas Penyelenggaraan Kewenangan Dalam Sistem Pemerintahan Daerah Di Indonesia, Pustaka Refleksi, Makasar 2010, Hlm. 35

${ }^{6}$ Nafisakhatul Layliyah, Wewenang Dalam Hukum Administrasi Negara, Artikel, https://www.researchgate.net/publication/336848033, Diakses pada tanggal 21 Juli 2020 Pukul 04.13

${ }^{7}$ Agus Roni Arbaben, Pengertian Kewenangan, Sumber-sumber Kewenangan dan Kewenangan Membentuk Undang-undang, https://agusroniarbaben.wordpress.com/2017/06/03/pengertian-kewenangansumber-sumber-kewenangan-dan-kewenangan-membentuk-undang-undang/,Diakses pada tanggal 14-032021 Pukul 22.49 Wib
} 
Management: Authority/Wewenang dalam Hukum Administrasi Negara adalah hak yang cukup, yang memungkinkan seseorang dapat menyelesaikan suatu tugas/kewajiban tertentu. Jadi, wewenang adalah dasar untuk bertindak, berbuat dan melakukan kegiatan/aktivitas perusahaan. Tanpa wewenang orang-orang tidak dapat berbuat apa-apa. ${ }^{8}$

Dalam suatu negara hukum-demokratis, tindakan pemerintah meletakkan suatu kewajiban atau beban bagi rakyatnya, hanya dapat dilakukan (halal) apabila memperoleh persetujuan dari rakyat melalui wakil-wakilnya di parlemen.Atribusi berarti adanyapemberian suatu wewenang (baru) oleh rakyat melalui wakilnya di parlemen kepada pemerintah, dimana wewenang tersebut sebelumnya tidak dimiliki oleh pemerintah. Dengan adanya pemberian wewenang itu berarti tindakan pemerintah menjadi sah (halal) dan secara yuridis mempunyai kekuatan mengikat umum, karena telah memperoleh persetujuan dari rakyat melalui wakilnya di parlemen, yang kemudian dituangkan dalam berbagai peraturan perundang-undangan baik di tingkat pusat maupun tingkat daerah. ${ }^{9}$

Delegasi adalah kewenangan yang dialihkan dari kewenangan atribusi dari suatu organ (institusi) pemerintahan kepada organ lainnya sehingga delegator (organ yang telah memberi kewenangan) dapat menguji kewenangan tersebut atas namanya, sedangkan pada Mandat, tidak terdapat suatu pemindahan kewenangan tetapi pemberi mandat (mandator) memberikan kewenangan kepada organ lain (mandataris) untuk membuat keputusan atau mengambil suatu tindakan atas namanya. ${ }^{10}$

\section{Pengertian BPK menurut Undang-undang}

BPK merupakan sebuah badan yang ada di dalam Sistem Ketatanegaraan Indonesia sejak masih jaman Hindia Belanda. Landasan hukum pembentukan BPK terdapat dalam UUD NRI Tahun 1945 sebelum dilakukannya perubahan (Pasal 23 ayat 5) maupun UUD NRI Tahun 1945 setelah dilakukannya perubahan (Pasal 23E - 23G). Salah satu tugas BPK adalah melakukan pemeriksaan terhadap pengelolaan dan tanggung jawab tentang keuangan negara.Kemudian hasil dari pemeriksaan tersebut harus diserahkan kepada DPR, DPD, dan DPRD untuk ditindaklanjuti oleh lembaga perwakilan dan/atau badan sesuai dengan undangundang.

\section{Tugas dan Kewenangan Badan Pemeriksa Keuangan atau BPK}

Mengenai tugas dan kewenangan tentang BPKP, juga termaktub dalam Peraturan Pemerintah Nomor 60 Tahun 2008 tentang Sistem Pengendalian Intern Pemerintah (PP No. 60/2008). Pembaharuan peraturan untuk menunjang eksistensi BPKP juga dilakukan terhadap Keppres No. 31/1983, yang diperbarui dengan ketentuan Peraturan Presiden Nomor 192 Tahun 2014 tentang Badan Pengawasan Keuangan dan Pembangunan (Perpres No. 192/2014). Tugas pemeriksaan BPK mencakup pemeriksaan keuangan, pemeriksaan kinerja dan pemeriksaan tujuan tertentu.Pemeriksaan terhadap pengelolaan dan tanggung jawab keuangan negara ini bertujuan untuk mendukung penegakan hukum atas penyimpangan keuangan Negara .Dalam prakteknya BPK melaksanakan ketiga kegiatan tersebut, yaitu :

${ }^{8}$ Moh. Mahfud MD, SF. Marbun, Wewenang Dalam Hukum Administrasi Negara, Jakarta: Airlangga, 2009, Hlm. 75

${ }^{9}$ SF. Marbun, Peradilan Administrasi Negara dan Upaya Administratif di Indonesia, Yogyakarta, FH UII Press, 2011, hlm. 137-138

${ }^{10}$ Sufriadi, Tanggung Jawab Jabatan Dan Tanggung Jawab Pribadi Dalam Penyelenggaraan Pemerintahan Di Indonesia, Jurnal Hukum, Universitas Islam Indonesia, Yogyakarta, 2014, Vol 1, No 1, Hlm. 62 
a. Fungsi operatif, yaitu berupa pemeriksaan, pengawasan, dan penyelidikan atas penguasaan, pengurusan dan pengelolaan kekayaan atas negara. Hal ini sudah jelas karena tugas BPK pada dasarnya melakukan pemeriksaan. Setiap tahun BPK Perwakilan DIY melakukan pemeriksaan Keuangan atas LKPD Pemda di DIY, pemeriksaan kinerja dan pemeriksaan dengan tujuan tertentu.

b. Fungsi yudikatif, yaitu berupa kewenangan menuntut perbendaharaan dan tuntutan ganti rugi terhadap perbendaharawan dan pegawai negeri bukan bendahara yang karena perbuatannya melanggar hukum atau melalaikan kewajiban yang menimbulkan kerugian keuangan dan kekayaan negara. Selama ini BPK Perwakilan DIY tidak melaksanakannya karena kewenangan menuntut perbendaharaan dan tuntutan ganti rugi terhadap perbendaharawan dan pegawai negeri bukan bendahara merupakan kewenangan BPK Pusat.

c. Fungsi advisory, yaitu memberikan pertimbangan kepada pemerintah mengenai pengurusan dan pengelolaan keuangan negara. Dalam pelaksanaannya BPK Perwakilan DIY terkadang menerima tamu yang berasal dari Pemerintah Daerah yang menyampaikan permasalahnpermasalahan yang dihadapi dalam pengelolaan keuangan di daerahnya. Dalam hal ini, BPK Perwakilan DIY akan memberikan pendapat atau masukan atas permasalahan yang dihadapi Pemerintah Daerah berdasarkan peraturan perundangan yang berlaku. ${ }^{11}$

\section{HASIL PENELITIAN}

\section{Kewenangan Akuntan Publik Dalam Melakukan Pemeriksaan Pengelolaan Keuangan Tahunan BPK Menurut Undang-Undang Nomor 15 Tahun 2006 Tentang Badan Pemeriksaan Keuangan.}

Akuntan publik merupakan individu yang telah memperoleh izin untuk memberikan jasa asuransi sesuai peraturan dan perundang-undangan di Indonesia. Akuntan Publik mempunyai peran penting dalam melakukan pemeriksaan pengelolaan keuangan tahunan terutama dalam peningkatan kualitas dan kredibilitas informasi keuangan atau laporan keuangan suatu entitas.Dalam hal ini Akuntan Publik mengemban kepercayaan masyarakat untuk memberikan opini atas laporan keuangan suatu entitas. ${ }^{12}$ Akuntan publik dituntut untuk senantiasa meningkatkan kompetensi dan profesionalisme agar dapat memenuhi kebutuhan pengguna jasa dan mengemban kepercayaan publik. Oleh karena itu, disusunlah UndangUndang tentang Akuntan Publik yang mengatur berbagai hal mendasar dalam profesi Akuntan Publik, dengan tujuan untuk:

1. melindungi kepentingan publik;

2. mendukung perekonomian yang sehat, efisien, dan transparan;

3. memelihara integritas profesi Akuntan Publik;

4. meningkatkan kompetensi dan kualitas profesi Akuntan Publik; dan

5. melindungi kepentingan profesi Akuntan Publik sesuai dengan standar dan kode etik profesi.

${ }^{11}$ Materna Ayu Novita Sekar Arum, Peran Badan Pemeriksa Keuangan Dalam Pemeriksaan Terhadap Pengelolaan Keuangan Negara Oleh Pemerintah Daerah, Tesis, Universitas Atma Jaya Yogyakarta, 2015, Hlm. 13

12 PenjelasanAtasUndang-Undang Republik IndonesiaNomor 5 Tahun 2011TentangAkuntan Publik 
Dalam memberikan jasa Akuntan Publik dituntut mengenali pengguna jasa dalam memutuskan melanjutkan klien yang ada atau menerima klien baru. Ini digunakan untuk menilai tingkat risiko dari klien sesuai dengan prosedur audit berbasis risiko. Akuntan publik akan memutuskan membatalkan atau menolak untuk memberikan jasa audit ketika klien tidak bersedia memberikan informasi untuk melihat tingkat risiko dari klien. Tingkat risiko yang dimiliki oleh perusahaan ditentukan dari sektor industri klien dan ukuran perusahaan. Perusahaan dalam kategori usaha kecil menengah maupun perusahaan go public tentu memiliki resiko sendiri. Akuntan akan menilai risiko dari pengguna jasa apakah perusahaan termasuk risiko rendah, sedang, atau tinggi yang berdampak pada penerapan profesional judgement yang didasarkan pada ketentuan peraturan perundang-undangan.

Dalam pasal 24, ditegaskan bahwa Akuntan Publik berhak untuk Memperoleh imbalan jasa, Memperoleh perlindungan hukum sepanjang telah memberikan jasa sesuai dengan SPAP, dan Memperoleh informasi, data, dan dokumen lainnya yang berkaitan dengan pemberian jasa sesuai dengan ketentuan peraturan perundang-undangan. dalam memberikan jasanya, akuntan public wajib mematuhi :

1. Standar profesional akuntan public yang ditetapkan oleh IAPI;

2. Etika profesi yang ditetapkan oleh IAPI; dan

3. Peraturan perundang-undangan yang berlaku, yang berhubungan dengan bidang jasa yang diberikan. ${ }^{13}$

Kewajiban-kewajiban yang diemban oleh akuntan public tersebut diharapkan dapat menjaga hubungan kepercayaan dengan masyarakat. Kewajiban pokok akuntan public lainnya dalam kaitannya hubungan kepercayaan, antara lain:

1. Perhatian terus menerus terhadap kebutuhan klien dan pihak-pihak lain yang berkepentingan

2. Pengembangan dan pemeliharaan pengetahuan dan keahlian yang dipersyaratkan

3. Pemeliharaan kepercayaan dengan menunjukkan perilaku yang secara etis bertanggungjawab

4. Pemeliharaan reputasi kepatutan sebagai pribadi

5. Pemeliharaan reputasi kredibilitas sebagai anggota profesi. ${ }^{14}$

Kehadiran seorang Akuntan Publik merupakan suatu hal yang sangat penting, khususnya bagi aktivitas berbisnis secara sehat di Indonesia. Hasil penelitian, analisa serta pendapat dari Akuntan Publik terhadap suatu laporan keuangan sebuah perusahaan akan sangat menentukan dasar pertimbangan dan pengambilan keputusan bagi seluruh pihak ataupun publik yang menggunakannya. Misalnya para investor dalam mempertimbangkan serta bahkan memutuskan kebijakan investasinya, para penasehat keuangan ataupun investasi dalam memberikan arahan pada para investor terhadap keadaan dan prospek dari perusahaan tersebut, para pemberi pinjaman (lenders) dalam mempertimbangkan serta memutuskan langkah pemberian ataupun penghentian pinjaman bagi perusahaan tersebut.

Peran Akuntan Publik lainnya adalah fasilitator dalam menghadirkan dirinya untuk memfasilitasi setiap potensi aktivitas bisnis yang melibatkan perusahaan tersebut, pelanggan dalam mempertimbangkan hubungan sekarang dan kedepannya dengan perusahaan tersebut, pemerintah dalam memberikan pertimbangan hubungan bisnis ataupun pemberian izin ataupun kualifikasi sehubungan dengan aktivitas berbisnis dari perusahaan tersebut bahkan karyawan

${ }^{13}$ Peraturan Menteri Keuangan tentang Jasa Akuntan Publik, PMK NO. 17/PMK.01/2008, Pasal

${ }^{14}$ Kusmanadji, Etika Profesi Akuntansi Bisnis dan Pelayanan Pubik, Jakarta: Sekolah Tinggi Akuntansi Negara, Hlm. 9 
dari perusahaan tersebut sendiri misalnya, dalam melihat masa depan dari keberadaannya dalam perusahaan tersebut serta masyarakat lainnya. Pertanggungjawaban seorang Akuntan Publik terhadap kepercayaan publik yang diberikan kepadanya, menjadi dasar keharusan hadirnya kualitas kebenaran dari setiap hasil audit ataupun pemeriksaan laporan keuangan yang dilakukannya. Keharusan dalam memenuhi standar kualitas kebenaran tersebut, akan sangat berhubungan dengan kemampuan yang dimilikinya sebagai seorang professional yang mandiri. Pemaparan diatas baik menurut Perundang-undangan maupun pendapat para ahli yang tercantum dalam Karya Ilmiah dapat penulis analisa bahwa Kewenangan Akuntan Publik dalam melakukan pemeriksaan keuangan BPK sudah sangat jelas tertera dalam Peraturan Perundangundangan tentang Akuntan Publik maupun dalam Kode Etik Profesi Akuntan Publik itu sendiri.Dan sangat jelas bahwa Akuntan Publik ini yang paling sangat ditekankan disini yaitu Profesionalitas dalam menjalankan tugasnya tersebut, oleh karena itu diberi kewenangan seluasluasnya dalam mengembankan tugasnya tersebut.

Keberhasilan suatu Instansi BPK atau perusahaan-perusahaan besar itu terletak pada finansialnya, bagaimana perusahaan tersebut mengontrol keuangannya oleh karena itu perlu adanya Akuntan Publik untuk mengaudit keuangan Intansi BPK atau perusahaan tersebut. Oleh karena itu Akuntan public harus professional dalam menjalankan tugasnya.

\section{Mekanisme Pemeriksaan Pengelolaan Keuangan Tahunan BPK Oleh Akuntan Publik Menurut Undang-Undang Nomor 15 Tahun 2006 Tentang Badan Pemeriksaan Keuangan}

Mekanisme Pemeriksaan Pengelolaan Keuangan Tahunan Bpk Oleh Akuntan dalam melaksanakan praktiknya ada tiga macam jenis audit yang sering dilakukan oleh akuntan public, yaitu audit oprasional, audit kepatuhan, dan audit atas laporan keuangan. Dalam penulisan karya ilmiah ini penulis akan mencoba untuk mengkaji lebih dalam mengenai audit atas laporan keuangan. Audit operasional adalah tinjauan atas bagian tertentu dari prosedur serta metode operasional organisasi tertentu yang bertujuan mengevaluasi efesiensi serta efektifitas prosedur serta metode tersebut. ${ }^{15}$ Audit kepatuhan bertujuan untuk menentukan apakah klien telah mengikuti prosedur, tata cara, serta peraturan yang dibuat oleh otoritas yang lebih tinggi. ${ }^{16}$ Audit laporan keuangan merupakan salah satu bentuk jasa atestasi dimana akuntan public menerbitkan laporan tertulis berisi pendapat atau opininya mengenai apakah laporan historis tersebut telah disusun berdasarkan prinsip-prinsip akuntasi yang berlaku secara umum.

Standar audit yang telah ditetapkan dan disahkan oleh Ikatan Akuntan Indonesia terdiri dari sepuluh Standar yang dikelompokkan menjadi tiga kelompok besar, yaitu:

1. Standar Umum

a. Audit harus dilaksanakan oleh seorang atau lebih yang memiliki keahlian dan pelatihan teknis yang cukup sebagai auditor.

b. Dalam semua hal yang berhubungan dengan perikatan, independensi dalam sikap mental harus dipertahankan oleh auditor.

c. Dalam pelaksanaan audit dan penyusunan laporannya, auditor wajib menggunakan kemahiran profesionalnya dengan cermat dan seksama. Jadi standar umum mengatur tentang pribadi auditor, mengenai persyaratan kompetensi, sikap serta profesionalisme auditor dalam melaksanakan audit.

Jadi standar umum mengatur tentang pribadi auditor, mengenai persyaratan kompetensi, sikap serta profesionalisme auditor dalam melaksanakan audit.

\footnotetext{
${ }^{15}$ Alvin A. Arrens,Auditing dan Jasa Asuransi, Jakarta, Erlangga 2008, Hlm. 19

${ }^{16}$ Ibid.,
} 
2. Standar Pekerjaan Lapangan

a. Pekerjaan harus dilaksanakan sebaik-baiknya dan jika digunakan asisten harus disupervisi dengan semestinya.

b. Pemahaman memadai atas pengendalian intern harus diperoleh untuk merencanakan audit dan menentukan sifat, saat, dan lingkup pengujian yang akan dilakukan.

c. Bukti audit kompeten yang cukup harus diperoleh melalui inspeksi, pengamatan, permintaan keterangan, dan konfirmasi sebagai dasar memadai untuk menyatakan pendapat atas laporan keuangan yang diaudit.

3. Standar Pelaporan

a. Laporan auditor harus menyatakan apakah laporan keuangan telah disusun sesuai dengan prinsip akuntansi yang berlaku umum di Indonesia.

b. Laporan auditor harus menunjukkan, jika ada, ketidakkonsistenan penerapan prinsip akuntansi dalam penyusunan laporan keuangan periode berjalan dibandingkan dengan penerapan prinsip akuntansi tersebut dalam periode sebelumnya.

Menurut Penulis Kewenangan Akuntan Pubik dalam melakukan pemeriksaan keuangan BPK meliputi berbagai tahap, adapun tahapan yang dilalui dalam melakukan pemeriksaan keuangan tersebut harus mengacu kepada Undang-Undang Nomor 15 Tahun 2006 tentang Badan Pemeriksaan Keuangan, sedangkan peraturan Perundang-undangan tentang Akuntan Publik hanya mengatur tentang keseluruhan tatacara berdirinya suatu Akuntan Publik tersebut bukan tata cara proses mekanisme pekerjaannya dalam mengaudit keuangan tersebut. Adapun tahapan yang harus dilalui Akuntan Publik dalam mengaudit keuangan BPK sesuai UndangUndang Nomor 15 Tahun 2006 tentang Badan Pemeriksaan Keuangan yaitu tahapan penerimaan penugasan audit, tahapan perencanaan audit, tahapan pelaksanaan audit, dan tahapan laporan audit, dan kemudian diserahkan kepada BPK itu sendiri.

Berdasarkan uraian diatas dapat disimpulkan bahwa mekanisme dalam pemeriksaan suatu perusahaan ataupun suatu instansi lembaga Negara maupun lainnya dilaksanakan sesuai dengan aturan perundang-undangan yang berlaku.

\section{KESIMPULAN}

Berdasarkan hasil penelitian ini maka dapat disimpulkan bahwa:

1. Kewenangan Akuntan Publik dalam melakukan pemeriksaan pengelolaan keuangan tahunan BPK menurut Undang-undang Nomor 15 Tahun 2006 tentang Badan Pemeriksaan Keuangan diimplementasikan berdasarkan Pasal 32 ayat 1 sebagaimana diketahui bahwa pemeriksaan pengelolaan dan tanggung jawab keuangan tahunan BPK dilakukan oleh akuntan publik. Secara umum kewenangan akuntan publik berhak melakukan audit terhadap lembaga BPK.Akan tetapi tidak begitu spesifik dapat ditemukan suatu data tentang kewenangan akuntan publik mengaudit BPK,mengingat didalam Peraturan Pemerintah Nomor 20 Tahun 2015 tentang Akuntan Publik hanya mengatur tata cara secara umum,tidak terlihat adanya suatu tata cara yang konkrit.

2. Mekanisme pemeriksaan pengelolaan keuangan tahunan BPK oleh akuntan publik berdasarkan Undang-undang Nomor 15 Tahun 2006 tentang Badan Pemeriksaan Keuangan dilakukan berdasarkan undang-undang yang berlaku, akan tetapi disini terdapat suatu kekurangan yang sangat mendasar, dimana pada Pasal 32 ayat 2 sebagaimana diketahui bahwa pemeriksaan keuangan tahunan BPK dilakukan oleh akuntan publik yang anggotanya ikut andil dipilih oleh lembaga BPK 
tersendiri.Berdasarkan perihal tersebut disini terdapat suatu kekurangan yang sangat serius pada pasal tersebut.

\section{DAFTAR PUSTAKA}

Agus Roni Arbaben, Pengertian Kewenangan, Sumber-sumber Kewenangan dan Kewenangan Membentuk Undangundang,https://agusroniarbaben.wordpress.com/2017/06/03/pengertian-kewenangan-sumbersumber-kewenangan-dan-kewenangan-membentuk-undang-undang/,Diakses pada tanggal 1403-2021 Pukul 22.49 Wib

Fakultas Hukum Universitas Malikussaleh, 2015, Buku Panduan Akademik, Lhoksemawe, Unimal Press, hlm. 106.

Kamal Hidjaz, Efektifitas Penyelenggaraan Kewenangan Dalam Sistem Pemerintahan Daerah Di Indonesia, Pustaka Refleksi, Makasar 2010, Hlm. 35

Materna Ayu Novita Sekar Arum, Peran Badan Pemeriksa Keuangan Dalam Pemeriksaan Terhadap Pengelolaan Keuangan Negara Oleh Pemerintah Daerah, Tesis, Universitas Atma Jaya Yogyakarta, 2015, Hlm. 13

Mardiasmo, PerwujudanTransparansi dan Akuntabilitas Publik melalui akuntasi sector Publik, Jurnal Akuntansi Pemerintahan, VOL 2 No. 1 Mei 2006.

Moh. Mahfud MD, SF. Marbun, Wewenang Dalam Hukum Administrasi Negara, Jakarta: Airlangga, 2009, Hlm. 75

Rini Wulandari, Skripsi: Badan Pemeriksaan Keuangan Dalam Kajian Ketatanegaraan Islam,Fakultas Syariah dan Hukum Universitas Islam Negeri Syarif Hidayatullah, Jakarta 2008, Hal. 1

SF. Marbun, Peradilan Administrasi Negara dan Upaya Administratif di Indonesia, Yogyakarta, FH UII Press, 2011, hlm. 137-138

Sufriadi, Tanggung Jawab Jabatan Dan Tanggung Jawab Pribadi Dalam Penyelenggaraan Pemerintahan Di Indonesia, Jurnal Hukum, Universitas Islam Indonesia, Yogyakarta, 2014, Vol 1, No 1, Hlm. 62 